\title{
JACK D. IVES AND THE GEOECOLOGY OF MOUNTAIN AREAS
}

\section{Jack D. Ives y la geoecología de las áreas de montaña}

\author{
J. J. GonZÁlez-TRueba ${ }^{1}$ AND J. M. García-Ruiz ${ }^{2}$ \\ 1 CIESE-C, Campus Internacional de la Universidad de Cantabria, \\ Avda. de la Universidad Pontificia, s/n, 39520 Comillas, Cantabria, Spain \\ 2 Instituto Pirenaico de Ecología, CSIC, Campus de Aula Dei, \\ Apartado 13.034, 50080 Zaragoza, Spain
}

\begin{abstract}
A short description of the work of Jack D. Ives is presented, as a tribute to this protagonist in the development of geoecological studies in mountain areas. His research in arctic and mountain environments (particularly the Rocky Mountains and the Himalayas) has provided a new global perspective, in which human activities and the organisation of human societies are the major factors explaining the complexity of mountain environments.
\end{abstract}

Keywords: Geoecology, Global geography, Mountains, Development.

RESUMEN.- Se hace una breve presentación de la obra de Jack D. Ives, uno de los grandes protagonistas del desarrollo de los estudios de Geoecología en las áreas de montaña. Con sus trabajos en ambientes fríos y de montaña (Montañas Rocosas e Himalaya, especialmente), Jack D. Ives ha proporcionado una nueva perspectiva global en la que la forma en que se organizan los grupos humanos y sus actividades son factores decisivos para explicar la complejidad de los ambientes de montaña.

Palabras clave: Geoecología, Geografía global, Montañas, Desarrollo. 


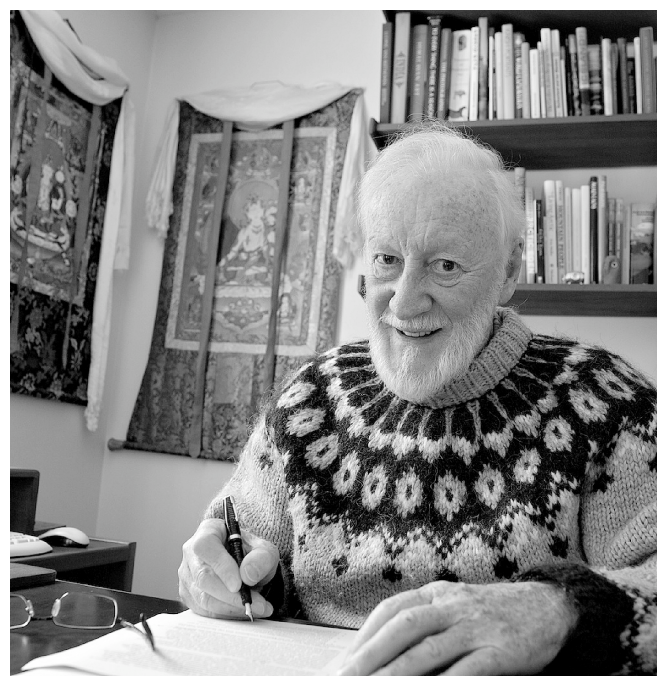

Professor Jack D. Ives at his office in Canada, 2011 (Photo: Hand-Ludwing Blohm).
From a geographical point of view, mountain areas have been the object of many studies in recent decades, and the subject of specialized articles and books taking a global perspective of the problems and challenges that mountains face because of Global Change processes, including increasing lowland demand for water resources, loss of social cohesion, farmland abandonment in some cases, and increasing human pressures on natural resources in others. Some scientific journals have emphasized the treatment of mountain areas as special territories that have strict limits imposed by the physical environment, great spatial and temporal heterogeneity in the availability of resources, and exhibit cultural adaptation and the presence of dramatic landscapes containing complex biodiversity, the functionality of which can influence the quality of life of both mountain and lowland populations. Among these journals, Mountain Research and Development, Arctic, Antarctic and Alpine Research, Pirineos, Revue de Géographie Alpine, and Journal of Mountain Science, are prominent, together with many others that frequently include papers on the hydrology, geomorphology, soil erosion and land use changes in mountain regions. Mountain Research and Development was founded in 1981 by Professor Jack D. Ives, and has played a marked role in consolidating a particular perception of mountain environments, and encouraging the study of remote, poorly accessible territories.

Professor Jack D. Ives was central to the evolution of this perception. His career, more than 50 years ago, was focused on the world's mountains and high latitudes, to which he contributed as a scientific researcher, teacher, and administrator committed to the sustainable development of these areas.

Jack was born in Grimsby, UK, in 1931. He graduated in Geography at the University of Nottingham in 1953. During his years as a university student he led three expeditions to the Iceland (particularly Skaftafell and Vatnajökull; e.g. see King and Ives, 1955; Ives, 1991, 2007). He moved to Canada in 1954, and two years later completed his doctorate on Geography/Geomorphology 
at McGill (Montreal) University. Shortly afterwards, he was appointed for a period of three years as Director of the McGill Sub-Arctic Research Laboratory in Nouveau Quebec-Labrador. Jack subsequently held positions of responsibility in various institutions, making a deep impression on each through the quantity and quality of his research and administrative efforts. The positions held included Assistant Director and Director of the Geographical Branch, Energy, Mines and Resources of Canada (1960-1967), during which he organized a series of inter-disciplinary expeditions to Baffin Island, Professor of Geography (1967-1989) and Director of the Institute of Arctic and Alpine Research at the University of Colorado, Boulder, USA (1967-1979) where he contributed to knowledge of the dynamics of the upper forest limit and the spatial organization of geomorphic processes in mountain areas. He was Professor of Mountain Geoecology, University of California, Davis, from 1989 to 1997. It is also noteworthy that he played a prominent role in many of the great advances that underpinned the institutional development of Mountain Geoecology in its more applied aspects.

Ives himself points out at the beginning of one of the papers included in this issue, the terms 'Landscape Ecology' (landschatökologie) and 'Geoecology' in general and 'Mountain Geoecology' in particular are inextricably linked to the life and work of Carl Troll (1899-1975). Troll was the first to define Geoecology as the science of the total and complex interrelationships between organisms and their environmental factors (Troll, 1972), a definition that could also be applied to Ecology (Ives, 1980). Nevertheless, the geoecological perspective includes landscape dynamics and its spatial organization, which above all involves Physical Geography, but takes into account that a major part of the dynamics and organization is attributable to human activity. Mountain Geoecology achieved international recognition in 1968 when the Commission on High-Altitude Geoecology was founded within the International Geographical Union (IGU). The formation of the Commission was a logical result of Carl Troll assuming the Presidency of the IGU (196064). The first step in the recognition involved the organization in Mexico (1966) of the First International Symposium on Geoecology of the Mountainous Regions of the Tropical Americas, which resulted in an increase of interest in geoecological studies at a global scale. Finally, during the 1968 International Geographical Conference in New Delhi, the Commission on High-Altitude Geoecology was established. Professor Troll led the Commission until 1972, when serious health problems led to his resignation and Jack was elected to succeed him as chairman, a position he held until 1980, and again from 1988 to 1996.

During the first four years of operation, the Commission worked with the objective of developing geographical studies of the poorly known high 
mountain environments. Formation of the Commission in 1968 occurred at a time of growing recognition of the need for international and inter-disciplinary collaboration. This period included the establishment of the International Biological Programme (IBP), the UNESCO Man and the Biosphere (MaB) Programme, and especially the UN Conference on the Human Environment (Stockholm, 1972). The MaB Programme comprised 14 projects, the sixth of which (MaB-6) was dedicated to the study of the impacts of human activity on mountain ecosystems. Jack was elected chair of the International Working Group of the MaB-6 project during its first three years (1973-1975). As a consequence, during the 1976 International Geographical Conference in Moscow he proposed to change the name of the Commission. It became the Commission on Mountain Geoecology and Sustainable Development thus facilitating a close inter-relationship with MaB-6. This change implied an increase in the study of areas beyond the limits of the high mountain. Similarly, changes in study topics and objectives were accepted; these emphasized the applied character of the studies and the necessity of a geoecological approach committed to sustainable development of the world's mountain areas. Above all the urgency for closer collaboration among the human and natural sciences was recognized.

During the 1970's and 1980's Jack played an outstanding role in two institutional milestones. The first was his invitation to serve as scientific coordinator of the United Nations University (1977) project on Highland-Lowland Interactive Systems, later to be renamed Mountain Geoecology and Sustainable Development (1978-2000), and the second was the creation of the International Mountain Society (1980), initially located in Colorado. The society's main purpose was: "...to strive for a better balance between mountain environment, development of resources, and the well-being of mountain peoples...". The society's journal Mountain Research and Development (co-published with the United Nations University) was founded in 1981, with Jack and Pauline Ives serving as editor and assistant editor until 1999. By this time, the chairmanship of the Commission on Mountain Geoecology and Sustainable Development had passed to Professor Bruno Messerli (University of Bern, Switzerland). Professor Messerli was the major collaborator of Jack D. Ives and published a number of seminal books (see below) with him. Professor Messerli, was President of the IGU between 1996 and 2000.

The next event having international repercussions occurred during the 1992 United Nations Earth Summit (Rio de Janeiro), where greater attention was paid to mountain environments and inhabitants. Professor Ives played a central role in the inclusion of a special chapter devoted to mountains (Chapter 13 -Managing Fragile Ecosystems-Sustainable Mountain Development), 
which paved the way for 2002 being declared by the United Nations as the International Year of the Mountains.

Nevertheless, the development of Mountain Geoecology had no unique institutional framework. Books in which Jack participated directly have been milestones in the development of global knowledge of mountain areas, and he consistently underlined the importance of mountains to the survival and welfare of millions of people worldwide. He emphasized their climatic and hydrological effects, and the altitudinal organization of ecosystems, which concentrate many species in a short horizontal distance and call for land management systems that favour the conservation of natural resources. Among these books, Arctic and Alpine Environments (Ives and Barry, 1974) in particular is a monumental and important work dedicated to Professor Troll. It considers present and past physical, biotic and human factors that characterize mountain and arctic areas at a global scale. Several years later he published the reference book Geoecology of the Colorado Front Range: A Study of Alpine and SubAlpine Environments (Ives, 1980), which includes some of the most outstanding scientific papers published in relation to this area on glacial geology, geomorphology, glaciology, hydrology, climatology and plant ecology. The book The Himalayan Dilemma (Ives and Messerli, 1989) considered the Theory of Himalayan Environmental Degradation, and provided arguments that discounted the theory. Later he published Himalayan Perceptions: Environmental change and the well-being of mountain peoples (Ives, 2004). Hofer and Messerli (2006) again considered the degradation of the Himalayas in a study of the hydrological dynamics of the Ganges and Brahmaputra rivers which was published as Floods in Bangladesh, thus completing the third stage of the UNU Himalayan research. In Deforestation: social dynamics in watersheds and mountain ecosystems, Ives and Pitt (1988) studied the possible impact of humans on Himalayan ecosystems. In 1997 Ives and Messerli produced the reference book, Mountains of the World. A global priority, which was written as a contribution to Chapter 13 of Agenda 21 and presents a comprehensive review of the essential aspects of mountain areas from the point of view of culture, resources and development.

The contribution of Professor Ives to the study, knowledge, protection and development of mountain areas is incalculable. His position as Chairman of the Commission on Mountain Geoecology and Sustainable Development was central, as was his world view of the mountains as environments in which humans have a decisive role. He began his scientific life as a physical geographer passionate about glaciology and Ice Age history and about extreme environments including those of the timberline (e.g. see Ives and HansenBristow, 1983), which was a study interest of Carl Troll (e.g. Troll, 1973). He then developed a much broader view of the complexity of the mountain land- 
scapes that involved local populations, and argued for the importance of maintaining these populations to ensure mountain conservation (e.g. Ives, 1999). For these reasons, in recent years he has received three awards: The King Albert I Gold Medal (2002), the Patron's Medal of the Royal Geographical Society (2006) and the Icelandic Knight Cross of the Order of the Falcon (2007), which is the Iceland's highest award. However, arguably his most important contribution has been the example he has set for other scientists as a teacher, researcher and international champion of the mountains. His work has inspired the publication of numerous books, including that of Singh and Kaur (1985) Integrated mountain development, to which he and Bruno Messerli contributed as Consulting Editors; a major monograph on African mountains and highlands edited by Messerli and Hurni (1990); the review by P.B. Stone (1992) of the state of the world's mountains; the review by Martin F. Price (1995) of the European mountains, country by country; and Gerrard's (1990) book on mountain environments. In Spain, much of the Ives's perspective has been gathered in a collective book by García-Ruiz (1990), in recognition of the great scientists of the mountains.

\section{References}

García-Ruiz, J.M. (edr.), 1990. Geoecología de las áreas de montaña. Geoforma Ediciones, Logroño, $337 \mathrm{pp}$.

Gerrard, A.J., 1990. Mountain environments. Belhaven Press, London, 317 pp.

Hofer, T. \&Messerli, B., 2006. Floods in Bangladesh. History, dynamics and rethinking the role of the Himalayas. United Nations University Press, Tokyo, $468 \mathrm{pp}$.

Ives, J.D. (edr.), 1980. Geoecology of the Colorado Front Range: A study of Alpine and Subalpine environments. Westview Press, Boulder, CO, $484 \mathrm{pp}$.

Ives, J.D., 1999. The use of hillside environments for land husbandry: personal reflections. Mountain Research and Development, 19 (3), 173-177.

Ives, J.D., 1991. Landscape change and human response during a thousand years of climatic fluctuations and volcanism: Skaftafell, Southeast Iceland. Pirineos, 137, 5-50.

Ives, J.D. \& Barry, R.G. (eds.), 1974. Arctic and Alpine environments. Methuen, London, $999 \mathrm{pp}$.

Ives, J.D. \& Hansen-Bristow, K.J., 1983. Stability and instability of natural and modified upper timberline landscapes in the Colorado Rocky Mountains, USA. Mountain Research and Development, 3 (2), 149-155.

Ives, J.D. \& Messerli, B., 1989. The Himalayan dilemme. Reconciling development and conservation. Routledge, New York, 295 pp. 
Ives, J.D. \& Pitt, D.C. (eds.), 1988. Deforestation: social dynamics in watersheds and mountain ecosystems. Routledge, New York, $247 \mathrm{pp}$.

King, C.A.M. \& Ives, J.D., 1955. Glaciological observations on some of the outlet glaciers on the south-west Vatnajökull, Iceland.Pt I - Glaciar regime. Journal of Glaciology, 2 (18), 563-569.

Messerli, B. \&Hurni, H. (eds.), 1990. African mountains and highlands. Problems and perspectives. African Mountains Association, Marceline, Missouri, 450 pp.

Messerli, B. \& Ives, J.D. (eds.), 1997. Mountains of the World. A global priority. The Parthenon Publishing Group, London, 495 pp.

Price, M.F., 1995. Mountain research in Europe. An overview of MaB research from the Pyrenees to Siberia. Man and the Biosphere Series, Unesco and The Parthenon Publishing Group, Paris, 230 pp.

Singh, T.V. and Kaur, J. (eds.), 1985. Integrated mountain development. Himalayan Books, New Delhi, 424 pp.

Stone, P.B., 1992. State of the World's mountains. A global report. Zed Books Ltd., New York, $391 \mathrm{pp}$.

Troll, C., 1973. The upper timberlines in different climatic zones. Arctic and Alpine Research, 5 (3), 3-18. 